\title{
miRNAs as Modulators of Angiogenesis
}

\author{
Shira Landskroner-Eiger, Isabelle Moneke, and William C. Sessa \\ Department of Pharmacology and Vascular Biology and Therapeutics Program, \\ Yale University School of Medicine, New Haven, Connecticut 06519 \\ Correspondence: William.sessa@yale.edu
}

MicroRNAs are highly expressed in endothelial cells, and recent data suggest that they regulate aspects of vascular development and angiogenesis. This study highlights the state of the art in this field and potential therapeutic opportunities. MicroRNAs (miRNAs) represent a family of conserved short $(\approx 22 \mathrm{nt})$ noncoding single-stranded RNAs that have been identified in plants and animals. They are generated by the sequential processing of the RNA template by the enzymes Drosha and Dicer, and mature miRNAs can regulate the levels of gene expression at the posttranscriptional level. miRNAs participate in a diverse range of regulatory events via regulation of genes involved in the control of processes such as development, differentiation, homeostasis, metabolism, growth, proliferation, and apoptosis. However, rather than functioning as regulatory on-off switches, miRNAs often function to modulate or fine-tune cellular phenotypes. So far, more than 1000 mammalian miRNAs have been identified since the discovery of the first two miRNAs (lin-4 and let-7), and bioinformatics predictions indicate that mammalian miRNAs can regulate $\sim 30 \%$ of all protein-coding genes.

Mi icroRNAs (miRNAs) can be encoded in independent transcription units, in polycistronic clusters, or within the introns of protein-coding genes. For further reading on biogenesis of miRNAs, refer to reviews by Bartel (2004) and He and Hannon (2004). The rules that guide miRNA-mRNA interactions are complex and are still under investigation. However, the current paradigm states that a WatsonCrick pairing between the mRNA and the $5^{\prime}$ region of the miRNA centered on nucleotides $2-7$, termed the "seed sequence," is required for miRNA-mediated inhibition (Bartel 2009). This model has recently been refined to account for the presence of secondary structure and other features of the $3^{\prime}$-untranslated region (UTR) sequence surrounding the target site and for the ability of complementarity at the $3^{\prime}$ end of the cognate miRNA to compensate for imperfect seed matching (Stefani and Slack 2008). It is important to note that identifying functionally important miRNA targets is crucial for understanding miRNA functions. However, the possibility that a single miRNA may target multiple transcripts within a cell type and that individual transcripts may be subject to regulation by multiple miRNAs amplifies the scope of putative miRNA regulation of gene expression and indicates that the particular cellular context of a given miRNA will determine

Editors: Michael Klagsbrun and Patricia D'Amore

Additional Perspectives on Angiogenesis available at www.perspectivesinmedicine.org

Copyright (C) 2013 Cold Spring Harbor Laboratory Press; all rights reserved; doi: 10.1101/cshperspect.a006643

Cite this article as Cold Spring Harb Perspect Med 2013;3:a006643 
S. Landskroner-Eiger et al.

its function in that specific cell type (Suarez and Sessa 2009). The purpose of this article is to highlight the role of miRNAs in angiogenesis.

\section{ROLE OF Dicer IN ENDOTHELIAL CELL FUNCTION AND ANGIOGENESIS}

To examine the spectrum of the significance of miRNAs, experiments using mutation or disruption of the rate-limiting enzyme involved in the maturation of miRNAs, Dicer, were carried out by several groups. This global loss of Dicer in mice leads to lethality at embryonic day 7.5 (E7.5), with embryos that are depleted of pluripotent stem cells (Bernstein et al. 2003). Mice hypomorphic for Dicer (Dicer ${ }^{\mathrm{ex} 1 / 2}$ ) die between days 12.5 and 14.5 of gestation and have defective blood vessel formation, implying that Dicer is necessary for normal mouse development (Yang et al. 2005). The importance of Dicer was reinforced using offspring of zebrafish that lack both maternal and zygotic Dicer, which exhibited severe defects in gastrulation, brain morphogenesis, and cardiac development associated with a disrupted blood circulation (Giraldez et al. 2005). To further explore the consequences of Dicer deletion, several laboratories have generated mice harboring tissue-specific inactivation of Dicer. This has led to the conclusion that Dicer is essential for the differentiation and/or function of many tissues, including germ cells (Murchison et al. 2005, 2007; Tang et al. 2007), neurons (Cuellar et al. 2008), T-cell development (Cobb et al. 2005; Liston et al. 2008), and skeletal muscle (O'Rourke et al. 2007). For example, cardiac-specific deletion of Dicer produced dilated cardiomyopathy associated with heart failure in neonates (Chen et al. 2008) and spontaneous cardiac remodeling when Dicer deletion was induced postnatally in the myocardium (da Costa Martins et al. 2008).

A role for Dicer in angiogenesis was reported by several groups (Yang et al. 2005; Kuehbacher et al. 2007; Suarez et al. 2007, 2008) as suggested from the phenotypes of Dicer $^{\text {ex } 1 / 2}$ mice (Yang et al. 2005). Defects observed in Dicer ${ }^{\text {ex } 1 / 2}$ embryos and yolk sacs were associated with altered expression of
VEGF and its receptors KDR (VEGFR2) and FLT-1 (VEGFR1), as well as the putative angiopoietin-2 receptor, Tie-1. This study suggested that Dicer has a role in embryonic angiogenesis, probably through processing of miRNAs that regulate expression levels of key angiogenic regulators (Yang et al. 2005; Suarez and Sessa 2009). In a similar context of global Dicer hypomorphic mice, the female infertility in this mouse line $\left(\right.$ Dicer $^{\mathrm{d} / \mathrm{d}}$ ) was caused by corpus luteum (CL) insufficiency, which results, at least in part, from an impairment of new capillary vessel growth in the ovary (Otsuka et al. 2007, 2008). The impaired CL angiogenesis in $\operatorname{Dicer}^{d / d}$ mice was partly due to a lack of miR17-5p and let7b, two miRNAs that were found to participate in the endothelial function of angiogenesis. Although CL angiogenesis was reduced, embryonic vasculogenesis and angiogenesis were not affected in Dicer ${ }^{\mathrm{d} / \mathrm{d}}$ mice, indicating that angiogenesis in different tissues has different sensitivities to the levels of Dicer protein (Otsuka et al. 2007, 2008). Overall, these observations gave rise to a series of in vitro studies to examine the global functional role of miRNAs in endothelial cells. Silencing of Dicer using short interfering (si)RNA in human endothelial cells (ECs) resulted in impaired development of capillary-like structures and reduced cell growth (Kuehbacher et al. 2007; Suarez et al. 2007, 2008). As expected, the knockdown of Dicer in ECs altered protein expression patterns of regulators in quiescent and activated endothelial biology, such us Tie-2/TEK, VEGFR2, endothelial nitric oxide synthase (eNOS), interleukin-8, and angiopoietin-like 4 (ANGPTL4) (Suarez et al. 2007). Interestingly, the Dicer silencing in ECs increased the expression of thrombospondin-1 (Tsp1) (Kuehbacher et al. 2007; Suarez et al. 2008), a multidomain matrix glycoprotein that has been shown to be an endogenous inhibitor of angiogenesis, which may explain, in part, the antiangiogenic phenotypes observed in vitro (Suarez and Sessa 2009).

To examine the role of Dicer in postnatal angiogenesis in vivo and, in turn, the implication of miRNA processing on EC biology, several approaches were used. Specifically, subcutaneous 
miRNAs as Modulators of Angiogenesis

injection of Dicer knockdown in HUVECs (suspended in a Matrigel plug) into nude mice showed reduced sprout formation (Kuehbacher et al. 2007). An additional approach generated two EC-specific Dicer knockout mouse lines, conditional Tie2-Cre;Dicer ${ }^{\text {flox/flox }}$ mice, and the tamoxifen-inducible VECad-Cre-ER ${ }^{\mathrm{T} 2}$; Dicer $^{\text {flox/flox }}$ mice (Suarez et al. 2008). Despite the fact that Dicer mRNA and protein levels were markedly reduced and miRNA production was diminished in ECs isolated from Tie2Cre;Dicer ${ }^{\text {flox/flox }}$ mice, they were viable and overtly normal, suggesting that the mice were either hypomorphic for Dicer expression or several long-lived miRNAs permitted EC survival. Similar to cultured ECs with reduced Dicer levels (Kuehbacher et al. 2007; Suarez et al. 2007), VEGF-driven angiogenesis was reduced in mice with conditional EC-specific loss of Dicer (Suarez et al. 2008). In addition, inactivation of Dicer in ECs reduced the angiogenic response to limb ischemia, as indicated by a reduction in capillary densities and blood flow recovery (Suarez et al. 2008). Similarly, the loss of Dicer in ECs reduced tumor and wound healing angiogenesis. For further reading on this topic, refer to a recent review (Suarez and Sessa 2009). In summary, these experimental approaches have begun to unveil the consequences of a deficit in miRNA biogenesis in EC biology.

It is important to keep in mind when interpreting these types of experiments, that noncanonical pathways for both Dicer and Drosha function as well as miRNA biogenesis are currently topics of investigation. Specifically, it was found that Dicer may participate in other processes unrelated to miRNA biology, such as formation of the heterochromatin (Fukagawa et al. 2004), in addition to data supporting Dicer-independent miRNA biogenesis pathways as well as Drosha-independent pri-miRNA processing pathways (Ruby et al. 2007; Cheloufi et al. 2010; Cifuentes et al. 2010). Given that the working hypothesis in the field is that changes in miRNA expression modulate the "robustness" of gene expression that governs function of the cell and its microenvironment, endothelial-derived miRNA biogenesis can clearly govern EC quiescence versus EC activation during angiogenesis. Deciphering the specific miRNA network responsible for the observed modulation of angiogenesis might prove to be a valuable tool in the clinic in various human pathologies, especially those involving the vasculature.

\section{miRNA MODULATING ENDOTHELIAL FUNCTIONS}

Mounting evidence indicates that there is an imbalance of miRNA levels in many diseases such as cancer, heart disease, or neurodegeneration. Whether this imbalance is the underlying cause or a consequence remains to be investigated. In any case, miRNAs provide promising potential therapeutic targets, especially because many miRNAs show striking organ-specific expression patterns, and different miRNAs have been specifically cloned from heart, brain, embryonic stem cells, and pancreatic islet cells, suggesting cell-type-specific functions (Houbaviy et al. 2003; Poy et al. 2004; Giraldez et al. 2005; Wienholds et al. 2005; Yang et al. 2005).

Support for the potential involvement of miRNAs in angiogenesis was first suggested in 2006 using miRNA microarrays as a discovery tool describing the presence of miRNA in ECs (Poliseno et al. 2006). In this article, using an early-stage miRNA microarray platform, 27 highly expressed miRNAs were identified in human umbilical vein endothelial cells (HUVECs), 15 of which were predicted to regulate the expression of receptors for angiogenic factors. In particular, they demonstrated that miR-221 and miR-222 affect the expression of $\mathrm{c}$-Kit and, as a consequence, the angiogenic properties of its ligand, stem cell factor, in vitro (Poliseno et al. 2006). Additional miRNA profiling studies by other groups identified a total of 200 miRNAs that are thought to be expressed by endothelial cells. Overall, there are 28 miRNAs that were identified in more than half (five out of eight) of the profiling studies (Heusschen et al. 2010). For a summary of miRNAs with known functional role in ECs, view Table 1. 


\section{S. Landskroner-Eiger et al.}

Table 1. miRNAs with validated roles in angiogenesis

\begin{tabular}{|c|c|c|c|}
\hline miRNA & $\begin{array}{l}\text { Validated targets in } \\
\text { the endothelium }\end{array}$ & Role in angiogenesis & References \\
\hline Let-7 family & $\begin{array}{l}\text { TIMP-1 (Let7b and } \\
\text { miR17b) }\end{array}$ & Promote EC proliferation and motility. & Otsuka et al. 2008 \\
\hline miR-10a & MAP3K7; TAK1 $\beta$ TRC & $\begin{array}{l}\text { Regulation of proinflammatory endothelial } \\
\text { phenotypes in athero-susceptible regions in } \\
\text { vivo. }\end{array}$ & Fang et al. 2010 \\
\hline miR-17-92 & $\begin{array}{l}\text { (A) TSP-1 (miR18a) } \\
\text { (B) TIMP-1 (miR17-5) } \\
\text { (C) ITG5a (miR92a) } \\
\text { (D) Jak1 (miR17- 5/ } \\
\text { miR20a) }\end{array}$ & $\begin{array}{l}\text { (A,B) Overexpression (miR17/5,18a,20a) into } \\
\text { Dicer-depleted cells promotes cell } \\
\text { proliferation and cord formation. Converse } \\
\text { effects by inhibition. } \\
\text { (C,D) Overexpression of individual } \\
\text { components inhibited spheroid cell } \\
\text { sprouting, network formation, and cell } \\
\text { migration in vitro. In vivo, miR92 } \\
\text { antagomirs promoted neovascularization in } \\
\text { ischemic limbs and improved cardiac } \\
\text { function in a model of myocardial } \\
\text { infarction. }\end{array}$ & $\begin{array}{l}\text { Otsuka et al. 2008; } \\
\text { Suarez et al. 2008; } \\
\text { Bonauer et al. } \\
\text { 2009; Doebele } \\
\text { et al. } 2010\end{array}$ \\
\hline miR-126 & SPRED-1, PIK3R2, VCAM1 & $\begin{array}{l}\text { Required for vascular integrity and } \\
\text { angiogenesis in vivo. A role in regulating the } \\
\text { adhesion of leukocytes to the endothelium. }\end{array}$ & $\begin{array}{l}\text { Fish et al. 2008; } \\
\text { Harris et al. 2008; } \\
\text { Wang et al. } 2008\end{array}$ \\
\hline miR-130a & GAX, HOXA5 & $\begin{array}{l}\text { Overexpression antagonized the inhibitory } \\
\text { effect of GAX on EC proliferation, } \\
\text { migration, and tube formation and the } \\
\text { inhibitory effects of HoxA5 on tube } \\
\text { formation. }\end{array}$ & $\begin{array}{l}\text { Chen and Gorski } \\
2008\end{array}$ \\
\hline miR-132 & p120RasGAP & $\begin{array}{l}\text { Ectopic expression in ECs increased } \\
\text { proliferation, tube formation, and Ras } \\
\text { activity. In vivo, antagomir vessel targeted } \\
\text { injection suppressed angiogenesis and } \\
\text { decreased tumor burden. }\end{array}$ & Anand et al. 2010 \\
\hline miR-210 & EphrinA3, NPTX1 & $\begin{array}{l}\text { Overexpression stimulates tube formation and } \\
\text { migration. Increased EC-mediated } \\
\text { angiogenesis. }\end{array}$ & $\begin{array}{l}\text { Fasanaro et al. 2008; } \\
\text { Pulkkinen et al. } \\
2008\end{array}$ \\
\hline miR-218 & $\begin{array}{l}\text { Robo1, Robo 2, glucuronyl } \\
\text { C5-epimerase (GLCE) }\end{array}$ & $\begin{array}{l}\text { Knockdown results in aberrant regulation of } \\
\text { Slit-Robo signaling axis, abnormal } \\
\text { endothelial cell migration, and reduced } \\
\text { complexity of the retinal vasculature. }\end{array}$ & Small et al. 2010 \\
\hline $\operatorname{miR}-221 / 222$ & $\mathrm{c}-\mathrm{KIT}$ & $\begin{array}{l}\text { Overexpression reduces tube formation, } \\
\text { migration, and wound healing in response } \\
\text { to SCF. }\end{array}$ & Poliseno et al. 2006 \\
\hline miR-222 & STAT5a & $\begin{array}{l}\text { miR-222 was down-modulated in endothelial } \\
\text { cells exposed to inflammatory stimuli. } \\
\text { Applying a gain-of-function approach } \\
\text { showed that miR-222 was involved in } \\
\text { inflammation-mediated vascular } \\
\text { remodeling. }\end{array}$ & $\begin{array}{l}\text { Poliseno et al. 2006; } \\
\text { Dentelli et al. } 2010\end{array}$ \\
\hline $\operatorname{miR}-296$ & HGS & $\begin{array}{l}\text { Inhibition reduces tube formation and } \\
\text { migration in vitro and angiogenesis in } \\
\text { tumor xenografts in vivo. }\end{array}$ & Wurdinger et al. 2008 \\
\hline miR-320 & IGF-1 & $\begin{array}{l}\text { Inhibition improves angiogenesis in diabetic } \\
\text { endothelial cells. }\end{array}$ & Wang et al. 2009 \\
\hline
\end{tabular}


miRNAs as Modulators of Angiogenesis

Emphasis on dissection of the relationships between specific miRNAs, signal transduction, and gene expression in vascular function has led to the realization that both highly expressed miRNAs as well as rarely detected miRNAs may play a role in fine-tuning endothelial cell physiology. Among the highly expressed miRNAs in ECs, miR-126 (also referred to as miR126-3p) is enriched in tissues with high vascular density such as the heart and lungs (Lagos-Quintana et al. 2002; Fish et al. 2008; Harris et al. 2008; Wang et al. 2008). In mammals and birds, miR-126 is encoded by intron 7 of the EGF-like domain 7 gene (Egfl7) and appears to have a similar pattern of endothelial expression as Egfl7 (Wang et al. 2008). Using human ECs in vitro, miR-126 was proposed to positively regulate endothelial cell migration, proliferation, and the stability of capillary tubes (Fish et al. 2008). ECs lacking miR-126 exhibit a diminished angiogenic response to growth factors such as VEGF and bFGF (Kuhnert et al. 2008; Wang et al. 2008) and have an increase in leukocyte adherence in the presence of TNF $\alpha$ stimulation (Harris et al. 2008). Two groups reported that mice null for miR-126 exhibit 40\% embryonic or perinatal death (Kuhnert et al. 2008; Wang et al. 2008), and the surviving miR-126 knockout neonates show delayed postnatal retinal and cranial angiogenesis (Kuhnert et al. 2008). Moreover, adult miR-126 knockout mice show impaired VEGF-dependent corneal angiogenesis (Kuhnert et al. 2008), as well as reduced survival and defective cardiac neovascularization following myocardial infarction (Wang et al. 2008). Mechanistically, the proangiogenic actions of miR-126 are mediated, at least in part, by promoting MAP kinase and PI3K signaling in response to VEGF and bFGF, through targeting negative regulators of these signaling pathways, including the Sprouty-related EVH-domain-containing protein Spred-1 and PI3K regulatory subunit 2 (PIK3R2/p85- $\beta$ ) (Fish et al. 2008; Kuhnert et al. 2008; Wang et al. 2008). miR-126 also targets vascular cell adhesion protein 1 (VCAM-1), thereby regulating the adhesion of leukocytes to the endothelium (Harris et al. 2008), suggesting a role of miR-126 in vascular inflammation. By targeting multiple signaling pathways, miR-126 may fine-tune angiogenic responses.

The miR-17 $\sim 92$ cluster, also named OncomiR-1, was the first identified tumor-promoting miRNA. This miRNA cluster is a polycistronic miRNA gene encoding for six miRNAs (miR-17, miR-18a, miR-19a, miR20a, miR-19b-1, and miR-92-a), which are tightly grouped within an $800-$ bp region of human chromosome 13 (Mendell 2008). Two paralogs of miR-17 92, miR-106a363 and miR-106b25, also exist in mammals. Genetic dissection revealed that mice lacking this cluster suffer from early postnatal lethality, with severe hypoplastic lungs, ventricular septal defects, and defects in B-cell development (Ventura et al. 2008). The defects in early B-cell development were partially explained by the direct repression of the proapoptotic gene BIM by this cluster at the pro- to pre-B-cell transition (Ventura et al. 2008). The human genomic locus of the miR17 92 cluster, C13orf25, is within 13q31, a genomic locus that is amplified in several types of lymphoma and solid tumors (Ota et al. 2004; He et al. 2005). miR-17 92 has been shown to cooperate with $\mathrm{c}-\mathrm{Myc}$ to induce B-cell lymphoma in mice (He et al. 2005). The pathological hallmarks of these animals included massive enlargement of lymph nodes, splenic hyperplasia, infiltration of the thymus by lymphoma cells, and leukemia. A link between miR-17 $\sim 92$ and tumorigenesis was further strengthened by the observation that overexpression of this cluster in thymocytes and pro-B-cells leads to hyperplasia of peripheral lymphoid tissues (Xiao et al. 2008). This phenotype was contributed by the targeting and down-regulation of the tumor-suppressor gene PTEN and the proapoptotic gene Bim via the miR-17 92 cluster (Xiao et al. 2008). Compatible with these results, genetic ablation of this cluster in a Myc-driven B-cell lymphoma leads to a dramatic suppression of tumorigenicity (Mu et al. 2009). In the latter case, members of the miR-19 family ( $m i R-19 a$ and $m i R-19 b$ ) were found essential to mediate the oncogenic activity of the entire cluster in part by modulating the expression of the tumor-suppressor gene PTEN (Mu et al. 2009). In 2006, the first 
S. Landskroner-Eiger et al.

paper linking this miRNA cluster indirectly to angiogenesis showed that colon cancer cells expressing the $\mathrm{c}-\mathrm{Myc}$ oncogene up-regulate the expression of the miR-17 92 cluster, which, in turn, represses the levels of the antiangiogenic molecules, thrombospondin-1 (Tsp-1) and a related molecule, connective tissue growth factor (CTGF) (Dews et al. 2006). Antisense experiments suggested that miR-19 was primarily responsible for Tsp 1 down-regulation and miR-18 for CTGF down-regulation in response to Myc (Dews et al. 2006). The investigators showed that the angiogenic activity of c-Myc, at least in part, is due to activation of the miR-17 $\sim 92$ cluster, which is sufficient to reduce Tsp1 and CTGF levels and promote angiogenesis and tumor growth, thus showing paracrine control of angiogenesis via tumorderived miRNAs. The specific function of members of this cluster in endothelial cells has been more directly addressed using isolated ECs. Suarez et al. (2008) showed a cell-intrinsic proangiogenic role for components of this cluster. Specifically, transfection of VEGF-regulated miRNAs (miR-17-5, miR-18a, mi-20a) into Dicer-depleted cells rescued and restored the defects in endothelial cell proliferation and organization that were initiated by the loss of Dicer (Suarez et al. 2007, 2008). Conversely, treatment with anti-miRs targeting miR17-5, $18 \mathrm{a}$, and 20a reduced the organization of VEGFstimulated HUVECs (Suarez et al. 2008). In part, this was explained by the targeting of the antiangiogenic protein Tspl by miR-18a (Suarez et al. 2008). Collectively, these data show that in the absence of miRNA processing (Dicer inactivation), VEGF-induced proliferation and morphogenesis are mediated, in part, by $\operatorname{miR}-17 \sim 92$ activation. As mentioned above, female infertility in this Dicer hypomorphic mouse line $\left(\right.$ Dicer $\left.^{d / d}\right)$ is caused by corpus luteum (CL) insufficiency, which results, at least in part, from an impairment of new capillary vessel growth in the ovary (Otsuka et al. 2007, 2008). The impaired CL angiogenesis in Dicer $^{d / d}$ mice was partly due to a lack of miR-17-5p and let7b, two miRNAs that were found to participate in the endothelial function of angiogenesis via regulation of the expression of the antiangiogenic factor tissue inhibitor of metalloproteinase 1 (TIMP1). Injections of miR-17-5p and let7b into Dicer ${ }^{d / d}$ mouse ovaries partially recovered the vascularity in the $\mathrm{CL}$, likely in part through the suppression of TIMP1 expression in Dicer ${ }^{d / d}$ mouse ovaries (Otsuka et al. 2008). Collectively, these data, in the context of low levels of Dicer1, suggest an important function of miR-17 92 in promoting angiogenesis.

Interestingly, antiangiogenic properties of members of the miR-17 92 cluster (Rayner et al. 2010) were reported in two different studies in cultured ECs (Bonauer et al. 2009; Doebele et al. 2010). Specifically, overexpression of the individual members of the miR17 $\sim 92$ cluster inhibited three-dimensionally (3D) spheroid cell sprouting, network formation, and cell migration (Doebele et al. 2010). Yet, only the combined inhibition of miR17 and miR20a by antagomir treatment in vivo enhanced vessel invasion into subcutaneous implanted Matrigel but not tumor angiogenesis. Relevant targets mediating the antiangiogenic activity of miR17 included the cell cycle inhibitor $\mathrm{p} 21$, the S1P receptor EDG1, and the protein kinase Jak1 (Doebele et al. 2010). Bonauer et al. (2009) further supported an antiangiogenic role for miR92a in ECs. Transfection of ECs with pre-miR92 in vitro blocked sprout formation, vascular network formation, endothelial cell migration and impaired adhesion to fibronectin, yet had no effect on proliferation of ECs (Bonauer et al. 2009). Accordingly, injection of miR-92a antagomirs into mice promoted neovascularization in ischemic limbs as shown by reduction in toe necrosis and recovery of blood flow and improved cardiac function in a model of myocardial infarction. This antiangiogenic action of miR-92a is mediated, at least in part, via repression of the $\alpha 5$ integrin subunit (Bonauer et al. 2009). Thus, in this study, miR-92a was identified as a repressor of the angiogenic program. Given that these in vivo experiments included systemic administration of antagomirs, which is most likely internalized by multiple cell types, it remains to be investigated as to the specific relevance of endothelial derived miR17 $\sim 92$ cluster in vivo 
miRNAs as Modulators of Angiogenesis

in both developmental and pathological angiogenesis.

A functional link between miR-296 and tumor-induced angiogenesis was shown in a primary culture of human brain microvascular ECs as well as in primary tumor ECs isolated from human brain tumors (Wurdinger et al. 2008). miR-296 was the only miRNA observed to be significantly up-regulated in the gliomainduced endothelial cells. Using a modified antisense miR-296 inhibitor resulted in a significant decrease in tube branching, tube length, and migration in the presence of a proangiogenic stimuli such as VEGF or glioma U87 cell-derived conditioned medium. The data support a positive regulatory role for miR-296 in the induction of tumor angiogenesis. The mechanisms of miR-296 regulation of endothelial biology is through targeting hepatocyte growth factor-regulated tyrosine kinase substrate (HGS), which degrades VEGF receptor 2 and platelet-derived growth factor receptor $\beta$ (Wurdinger et al. 2008). This suggests that endothelial activation by proangiogenic factors induces a positive feedback loop that increases the sensitivity of endothelial cells to additional proangiogenic stimuli.

miR-210 up-regulation is a crucial element in endothelial cell response to hypoxia (Fasanaro et al. 2008). In normoxic ECs, overexpression of miR-210 was shown to enhance tubulogenesis and VEGF-induced migration of HUVECs. Conversely, blockade of miR-210 inhibited tube formation and migration in response to VEGF, inhibited cell growth, and induced apoptosis, in both normoxia and hypoxia (Fasanaro et al. 2008). In keeping with this latter finding, it has been shown that miR-210 inhibition activates caspases (Kulshreshtha et al. 2007). One may speculate that the inhibitory effects on migration and tubulogenesis are mediated by enhanced apoptosis. One relevant target of miR-210 in hypoxia was Ephrin-A3, the eph-related receptor tyrosine kinase ligand 3. Ephrin-A3 modulation by miR210 via its down-modulation was a necessary event of miR-210-mediated stimulation of capillary-like formation and EC chemotaxis in response to VEGF and hypoxia (Fasanaro et al. 2008). In the developing cardiovascular system, Eph and ephrin molecules control the angiogenic remodeling of blood and lymphatic vessels and play essential roles in ECs, pericytes, and vascular smooth muscle cells (Kuijper et al. 2007). Taking a molecular approach encompassing proteomics, transcriptomics, bioinformatics, and biochemistry to investigate miR-210 function, Fasanaro et al. (2009) validated 31 new direct miR-210 targets, allowing better delineation of the molecular pathways underpinning miR-210 action. Limiting their analysis to those genes that exhibited inverse patterns when miR-210 was overexpressed or downregulated, Gene Ontology analysis of this study confirmed a role for miR-210 in differentiation and cell cycle regulation and highlighted new functions in RNA processing, DNA binding, membrane trafficking, and development (Fasanaro et al. 2009). Interestingly, the HIF1 $\alpha$ pathway was found to be the most enriched miR210-modulated pathway, suggesting a potential bidirectional relationship between miR-210 and the HIF pathway. Other enriched pathways, such as ATM, FAS, and TNFR1, correlated with the antiapoptotic role of miR-210 (Fasanaro et al. 2009).

Given the important characteristic of tissue- and cell-type-specific expression pattern of miRNAs, future studies of different endothelial cell sources using platforms with a broad miRNA coverage will provide a more comprehensive list of endothelial miRNAs and their role in the regulation of different aspects of the angiogenic response.

\section{REGULATION OF miRNA SYNTHESIS IN ECS}

ECs are exquisitely sensitive to a variety of signals, and emerging data now implicate several signaling pathways regulating EC miRNAs. For example, hypoxia triggers the expression of miR-210 in all cells tested including ECs (Kulshreshtha et al. 2007; Fasanaro et al. 2008). Importantly, HIF1 $\alpha$ was necessary and sufficient for miR-210 activation (Fasanaro et al. 2008). Hypoxia is a key determinant of tissue pathology and organ perfusion, and miR-210 was also shown to be up-regulated in 
S. Landskroner-Eiger et al.

rat models of cardiac hypotrophy/cardiac failure and in a model of transient focal ischemia (Wu et al. 2009). Thus, the compiled data suggest that the miR-210-mediated stimulation of capillary-like formation and EC chemotaxis in response to VEGF may contribute to modulate the angiogenic response to ischemia.

In exploring the possibility that VEGF may modulate the expression levels of miRNAs, which, in turn, may regulate aspects of the integrated angiogenic response, HUVECs were treated with VEGF, and expression of miRNAs was quantified using miRNA microarrays. It was reported that VEGF increased the expression of several miRNAs commonly overexpressed in human tumors (hsa-miR-155, -191, $-21,-17-5 p,-18 a$, and $-20 a)$ that have been further implicated in the control of tumor growth, survival, and angiogenesis (Chan et al. 2005; Cheng et al. 2005; Dews et al. 2006; Volinia et al. 2006). Interestingly, these miRNAs show low basal levels of expression in HUVECs but are induced after VEGF stimulation, suggesting that these miRNAs may regulate aspects of the angiogenic actions of VEGF.

More recently, the role of several cytokines mediating an miRNA-dependent response of ECs to an inflammatory milieu was tested. For example, atherosclerotic lesion progression requires intraplaque neovascularization, and the inflammatory cells contained in the neointima mainly contribute to this process by releasing cytokines and growth factors, such as IL-3 and bFGF (Dentelli et al. 1999). To evaluate the biological functions of miRNAs in inflammatory angiogenesis, ECs were exposed to IL-3 or bFGF, and the regulation of a subset of seven miRNAs, previously known to be involved in angiogenesis, was tested (miR-17-5p, miR-21, miR-126, miR-210, miR-221, miR-222, and miR-296) (Dentelli et al. 2010). Out of this list, a significant down-regulation of miR-296, miR-126, and miR-221/222 was detected in ECs, yet only overexpression of pre-miR222 resulted in failure to induce EC proliferation and migration in response to IL3 or bFGF (Dentelli et al. 2010). The biological relevance of miR-222 in regulating plaque progression was investigated by isolating human ECs from normal and atherosclerotic samples. miR-222 was highly expressed in ECs recovered from normal vessels and conversely, from early to advanced lesions, a progressively decreased expression of miR-222, whereas STAT5A, a direct target of miR222 in this context, was barely detectable in normal vessel, and its expression increased from early to advanced lesions. This study provided evidence that miR-222 is the main regulator of vascular cell biology in an inflammatory microenvironment containing IL-3 or bFGF and further identified STAT5A as a novel miR-222 target. An additional study focused on the role of bone morphogenetic protein receptor type II (BMPR2) in the development of pulmonary arterial hypertension. This study demonstrated that the miR-17 92 cluster is modulated by IL- 6 , a cytokine involved in the pathogenesis of pulmonary hypertension, via activation of a STAT3-responsive region located $100 \mathrm{bp}$ upstream of the start codon of C13orf25. In turn, BMPR2 is directly targeted by miR17-5p and miR-20a, leading to the conclusion that increased IL- 6 signaling leads to the downregulation of BMPR2, based on a phylogenetically conserved STAT3-miR-17 92 pathway (Brock et al. 2009).

The information about specific regulation of miRNAs via promoter elements has comparatively lagged behind, in contrast to the wealth of publications about the biological effects of miRNAs. In this regard, promoter elements that could contribute to the expression of the muscle-specific miR-1/miR-133 cluster have been identified, as well as miR-223 during granulopoiesis (Suarez and Sessa 2009). The oncogenic transcription factor c-Myc activates the miR-17 92 cluster, and this mechanism plays an important role in tumor formation (O’Donnell et al. 2005; Dews et al. 2006). In fact, six up-regulated miRNAs were consistently observed in the high c-Myc state: miR-17-5p, miR-18, miR-19, miR-20, miR-92, and miR106 (O’Donnell et al. 2005). The Ets family of transcription factors shares a highly conserved DNA-binding domain and regulates cell development, senescence, death, and tumorigenesis. Several members of the ETS 
miRNAs as Modulators of Angiogenesis

family are expressed in ECs and have been shown to play a role in vasculogenesis, angiogenesis, inflammation, and remodeling (Oettgen 2006). Ets family members Ets-1 and Ets-2 induce the expression of miR-126 in endothelial cells (Harris et al. 2010). Another example of promoter regulation of miRNAs in ECs involved investigating the process of how mechano-sensory stimulus of blood flow governs vascular patterning. During the development of the embryonic vascular system, Nicoli et al. (2010) observed that flow is essential for angiogenesis during aortic arch (AA) development using a zebrafish model. They further found that angiogenic sprouting of AA vessels required a flow-induced genetic pathway in which the mechano-sensitive zinc finger transcription factor $k l f 2 a$ induces expression of miR-126 to activate VEGF signaling (Nicoli et al. 2010). This work provided new insights into how EC response to flow can be integrated with early developmental signals to drive angiogenesis.

\section{THERAPEUTIC APPLICATIONS}

A growing number of reports have shown that a derailed expression pattern of microRNA levels is a common feature in many human diseases including those involving the vasculature such as cardiovascular disease, retinopathy, and cancer (Esquela-Kerscher and Slack 2006; Liu and Olson 2010). This has opened an exciting new avenue for targeted angiogenic therapies, and because a single miRNA can potentially regulate a plethora of endothelial functions by targeting multiple transcripts, miRNA-targeted therapy could profoundly influence an entire gene network and thereby modify complex endothelial cell function.

The roles of individual miRNAs in remodeling the angiogenic response in both developmental and pathological processes are just beginning to be revealed. miRs can promote angiogenesis by targeting negative regulators in angiogenic signaling pathways or inhibit angiogenesis by targeting positive regulators. Therefore, antagonism or mimicry of key miRNAs might be used to direct the angiogenic response in vivo and provide a novel approach for treatment of diseases with aberrant pathological angiogenesis. General therapeutic strategies include antisense-mediated inhibition of miRNAs and miRNA replacements with miRNA mimetics or viral vector-encoded miRNAs. Synthetic anti-miRNA oligonucleotides (AMOs) with 2'-O-methyl modification have been shown to be effective inhibitors of endogenous miRNAs both in vitro and in vivo. A single injection of modified AMOs conjugated with cholesterol termed "antagomirs" through intravenous injection to target the liver-specific miR-122 conferred specific miR-122 silencing for up to $23 \mathrm{~d}$ (Krutzfeldt et al. 2005). As an alternative to 2'-hydroxyl-modified AMOs, lock nucleic acid (LNA)-based oligonucleotides (LNA-antimiRs) have been shown to be more stable and less toxic in inhibiting endogenous miRNAs in vivo (Vester and Wengel 2004; Elmen et al. 2008). miRNA replacement therapy, although to a lesser extent, has also been examined in several in vivo cancer models. An alternative strategy to single anti-miRs, termed "miRNA sponges," includes transcripts expressed from strong promoters, containing multiple tandem binding sites to specific miRNAs that can competitively inhibit specific miRNAs (Ebert et al. 2007). One advantage of this latter system is that one could construct sponges and anti-miRNA decoys with a combination of miRNA-binding sites to potentially inhibit an entire miRNA cluster. For a broader scope of the different applications, see the review by Trang et al. (2008).

A potential pitfall of miRNA-based therapy are the off-target effects that are likely to occur because only partial complementarity between an miRNA and target mRNA transcripts is required (Heusschen et al. 2010). One way of circumventing this lack of gene specificity would be to block miRNA actions in a gene-specific manner by specifically disrupting the binding between an miRNA and its designated binding site. Gene-specific miRNA mimics and miRNA-masking antisense approaches to perturb miRNA-mRNA interactions in vitro have recently been described, although the applicability of these approaches 
S. Landskroner-Eiger et al.

still needs to be demonstrated in vivo (van Rooij and Olson 2007; Xiao et al. 2007).

A new area of exploration is the detection of miRNAs in body fluids as potential biomarkers for diagnosis of physiological processes (pregnancy) and various diseases such as myocardial infarction. Gilad et al. (2008) were able to detect miRNA in serum and urine and showed that the levels of three placental microRNAs (hsa-miR526a, hsa-miR-527, and hsa-miR-520d-5p) could be used to accurately distinguish pregnant from nonpregnant women. In other experimental models of acute myocardial infarction, several groups have shown that muscle-enriched miRNAs, such as miR-1, miR-133a, miR-499, and miR-208, are elevated in plasma, thus suggesting that circulating myocardial-derived miRNAs might be useful as potential biomarkers of infarction (D'Alessandra et al. 2010). Thus, circulating microRNAs in bodily fluids may represent useful clinical biomarkers.

Recent studies have identified a variety of miRNAs involved in angiogenic processes; therefore, modulating miRNA levels via either antagomirs or miRNA mimicry seems to be a promising target for future therapeutics. However, the incomplete understanding of the biology of miRNAs, the complexity of many miR targets, and the challenge of developing specific and efficient delivery systems targeting pathological versus physiological angiogenesis are needed before this exciting technology will come to its fruition. Lessons learned from antisense technologies and RNA interference approaches will no doubt be relevant in advancement of miRNA therapeutics. However, if key miRs can be identified that regulate entire pathways of angiogenic signaling, akin to approaches used to regulate multiple genes in the sterol-regulatory pathway (Rayner et al. 2010), targeting miRs may be an innovative opportunity to fine-tune the balance of normal versus abnormal angiogenesis.

\section{REFERENCES}

Ambros V. 2003. MicroRNA pathways in flies and worms: Growth, death, fat, stress, and timing. Cell 113: 673-676.

Anand S, Majeti BK, Acevedo LM, Murphy EA, Mukthavaram R, Scheppke L, Huang M, Shields DJ, Lindquist
JN, Lapinski PE, et al. 2010. MicroRNA-132-mediated loss of pp120RasGAP activates the endothelium to facilitate pathological angiogenesis. Nat Med 16: 909-914.

Bartel DP. 2004. MicroRNAs: Genomics, biogenesis, mechanism, and function. Cell 116: 281-297.

Bartel DP. 2009. MicroRNAs: Target recognition and regulatory functions. Cell 136: 215-233.

Bernstein E, Kim SY, Carmell MA, Murchison EP, Alcorn H, Li MZ, Mills AA, Elledge SJ, Anderson KV, Hannon GJ. 2003. Dicer is essential for mouse development. Nat Genet 35: 215-217.

Bonauer A, Carmona G, Iwasaki M, Mione M, Koyanagi M, Fischer A, Burchfield J, Fox H, Doebele C, Ohtani K, et al. 2009. MicroRNA-92a controls angiogenesis and functional recovery of ischemic tissues in mice. Science 324: 1710-1713.

Brennecke J, Hipfner DR, Stark A, Russell RB, Cohen SM. 2003. bantam encodes a developmentally regulated microRNA that controls cell proliferation and regulates the proapoptotic gene hid in Drosophila. Cell 113: 25-36.

Brock M, Trenkmann M, Gay RE, Michel BA, Gay S, Fischler M, Ulrich S, Speich R, Huber LC. 2009. Interleukin-6 modulates the expression of the bone morphogenic protein receptor type II through a novel STAT3-microRNA cluster 17/92 pathway. Circ Res 104: 1184-1191.

Chan JA, Krichevsky AM, Kosik KS. 2005. MicroRNA-21 is an antiapoptotic factor in human glioblastoma cells. Cancer Res 65: 6029-6033.

Cheloufi S, Dos Santos CO, Chong MM, Hannon GJ. 2010. A Dicer-independent miRNA biogenesis pathway that requires Ago catalysis. Nature 465: 584-589.

Chen Y, Gorski DH. 2008. Regulation of angiogenesis through a microRNA (miR-130a) that down-regulates antiangiogenic homeobox genes GAX and HOXA5. Blood 111: 1217-1226.

Chen CZ, Li L, Lodish HF, Bartel DP. 2004. MicroRNAs modulate hematopoietic lineage differentiation. Science 303: $83-86$.

Chen JF, Murchison EP, Tang R, Callis TE, Tatsuguchi M, Deng Z, Rojas M, Hammond SM, Schneider MD, Selzman $\mathrm{CH}$, et al. 2008. Targeted deletion of Dicer in the heart leads to dilated cardiomyopathy and heart failure. Proc Natl Acad Sci 105: 2111-2116.

Cheng AM, Byrom MW, Shelton J, Ford LP. 2005. Antisense inhibition of human miRNAs and indications for an involvement of miRNA in cell growth and apoptosis. Nucleic Acids Res 33: 1290-1297.

Cifuentes D, Xue H, Taylor DW, Patnode H, Mishima Y, Cheloufi S, Ma E, Mane S, Hannon GJ, Lawson ND, et al. 2010. A novel miRNA processing pathway independent of Dicer requires Argonaute2 catalytic activity. Science 328: 1694-1698.

Cobb BS, Nesterova TB, Thompson E, Hertweck A, O’Connor E, Godwin J, Wilson CB, Brockdorff N, Fisher AG, Smale ST, et al. 2005. T cell lineage choice and differentiation in the absence of the RNase III enzyme Dicer. J Exp Med 201: 1367-1373.

Cuellar TL, Davis TH, Nelson PT, Loeb GB, Harfe BD, Ullian E, McManus MT. 2008. Dicer loss in striatal neurons produces behavioral and neuroanatomical phenotypes in the 
miRNAs as Modulators of Angiogenesis

absence of neurodegeneration. Proc Natl Acad Sci 105: 5614-5619.

da Costa Martins PA, Bourajjaj M, Gladka M, Kortland M, van Oort RJ, Pinto YM, Molkentin JD, De Windt LJ. 2008. Conditional Dicer gene deletion in the postnatal myocardium provokes spontaneous cardiac remodeling. Circulation 118: 1567-1576.

D’Alessandra Y, Devanna P, Limana F, Straino S, Di Carlo A, Brambilla PG, Rubino M, Carena MC, Spazzafumo L, De Simone M, et al. 2010. Circulating microRNAs are new and sensitive biomarkers of myocardial infarction. Eur Heart J 31: 2765-2773.

Dentelli P, Del Sorbo L, Rosso A, Molinar A, Garbarino G, Camussi G, Pegoraro L, Brizzi MF. 1999. Human IL-3 stimulates endothelial cell motility and promotes in vivo new vessel formation. J Immunol 163: 2151-2159.

Dentelli P, Rosso A, Orso F, Olgasi C, Taverna D, Brizzi MF. 2010. MicroRNA-222 controls neovascularization by regulating signal transducer and activator of transcription 5A expression. Arterioscler Thromb Vasc Biol 30: $1562-1568$.

Dews M, Homayouni A, Yu D, Murphy D, Sevignani C Wentzel E, Furth EE, Lee WM, Enders GH, Mendell JT, et al. 2006. Augmentation of tumor angiogenesis by a Myc-activated microRNA cluster. Nat Genet 38: 1060-1065.

Dimmeler S, Zeiher AM. 2010. Circulating microRNAs: Novel biomarkers for cardiovascular diseases? Eur Heart J 31: 2705-2707.

Doebele C, Bonauer A, Fischer A, Scholz A, Reiss Y, Urbich C, Hofmann WK, Zeiher AM, Dimmeler S. 2010. Members of the microRNA-17-92 cluster exhibit a cell intrinsic anti-angiogenic function in endothelial cells. Blood 115: 4944-4950.

Ebert MS, Neilson JR, Sharp PA. 2007. MicroRNA sponges: Competitive inhibitors of small RNAs in mammalian cells. Nat Methods 4: 721-726.

Elmen J, Lindow M, Schutz S, Lawrence M, Petri A, Obad S, Lindholm M, Hedtjarn M, Hansen HF, Berger U, et al. 2008. LNA-mediated microRNA silencing in nonhuman primates. Nature 452: 896-899.

Esquela-Kerscher A, Slack FJ. 2006. Oncomirs-MicroRNAs with a role in cancer. Nat Rev Cancer 6: 259-269.

Fang Y, Shi C, Manduchi E, Civelek M, Davies PF. 2010. MicroRNA-10a regulation of proinflammatory phenotype in athero-susceptible endothelium in vivo and in vitro. Proc Natl Acad Sci 107: 13450-13455.

Fasanaro P, D’Alessandra Y, Di Stefano V, Melchionna R, Romani S, Pompilio G, Capogrossi MC, Martelli F. 2008. MicroRNA-210 modulates endothelial cell response to hypoxia and inhibits the receptor tyrosine kinase ligand Ephrin-A3.J Biol Chem 283: 15878-15883.

Fasanaro P, Greco S, Lorenzi M, Pescatori M, Brioschi M, Kulshreshtha R, Banfi C, Stubbs A, Calin GA, Ivan M, et al. 2009. An integrated approach for experimental target identification of hypoxia-induced miR-210. J Biol Chem 284: 35134-35143.

Fish JE, Santoro MM, Morton SU, Yu S, Yeh RF, Wythe JD, Ivey KN, Bruneau BG, Stainier DY, Srivastava D. 2008. miR-126 regulates angiogenic signaling and vascular integrity. Dev Cell 15: 272-284.
Fukagawa T, Nogami M, Yoshikawa M, Ikeno M, Okazaki T Takami Y, Nakayama T, Oshimura M. 2004. Dicer is essential for formation of the heterochromatin structure in vertebrate cells. Nat Cell Biol 6: 784-791.

Gilad S, Meiri E, Yogev Y, Benjamin S, Lebanony D, Yerushalmi N, Benjamin H, Kushnir M, Cholakh H, Melamed $\mathrm{N}$, et al. 2008. Serum microRNAs are promising novel biomarkers. PLoS One 3: e3148. doi: 10.1371/ journal.pone.0003148.

Giraldez AJ, Cinalli RM, Glasner ME, Enright AJ, Thomson JM, Baskerville S, Hammond SM, Bartel DP, Schier AF. 2005. MicroRNAs regulate brain morphogenesis in zebrafish. Science 308: 833-838.

Harris TA, Yamakuchi M, Ferlito M, Mendell JT, Lowenstein CJ. 2008. MicroRNA-126 regulates endothelial expression of vascular cell adhesion molecule 1. Proc Natl Acad Sci 105: 1516-1521.

Harris TA, Yamakuchi M, Kondo M, Oettgen P, Lowenstein CJ. 2010. Ets-1 and Ets-2 regulate the expression of microRNA-126 in endothelial cells. Arterioscler Thromb Vasc Biol 30: 1990-1997.

He L, Hannon GJ. 2004. MicroRNAs: Small RNAs with a big role in gene regulation. Nat Rev Genet 5: 522-531.

He L, Thomson JM, Hemann MT, Hernando-Monge E, Mu D, Goodson S, Powers S, Cordon-Cardo C, Lowe SW, Hannon GJ, et al. 2005. A microRNA polycistron as a potential human oncogene. Nature 435: 828-833.

Heusschen R, van Gink M, Griffioen AW, Thijssen VL. 2010 MicroRNAs in the tumor endothelium: Novel controls on the angioregulatory switchboard. Biochim Biophys Acta 1805: 87-96.

Houbaviy HB, Murray MF, Sharp PA. 2003. Embryonic stem cell-specific microRNAs. Dev Cell 5: 351-358.

Krutzfeldt J, Rajewsky N, Braich R, Rajeev KG, Tuschl T, Manoharan M, Stoffel M. 2005. Silencing of microRNAs in vivo with "antagomirs." Nature 438: 685-689.

Kuehbacher A, Urbich C, Zeiher AM, Dimmeler S. 2007. Role of Dicer and Drosha for endothelial microRNA expression and angiogenesis. Circ Res 101: 59-68.

Kuhnert F, Mancuso MR, Hampton J, Stankunas K, Asano T Chen CZ, Kuo CJ. 2008. Attribution of vascular phenotypes of the murine Egfl7 locus to the microRNA miR-126. Development 135: 3989-3993.

Kuijper S, Turner CJ, Adams RH. 2007. Regulation of angiogenesis by Eph-ephrin interactions. Trends Cardiovasc Med 17: 145-151.

Kulshreshtha R, Ferracin M, Wojcik SE, Garzon R, Alder H, Agosto-Perez FJ, Davuluri R, Liu CG, Croce CM, Negrini $\mathrm{M}$, et al. 2007. A microRNA signature of hypoxia. Mol Cell Biol 27: 1859-1867.

Lagos-Quintana M, Rauhut R, Yalcin A, Meyer J, Lendeckel W, Tuschl T. 2002. Identification of tissue-specific microRNAs from mouse. Curr Biol 12: 735-739.

Liston A, Lu LF, O'Carroll D, Tarakhovsky A, Rudensky AY. 2008. Dicer-dependent microRNA pathway safeguards regulatory T cell function. J Exp Med 205: 1993-2004.

Liu N, Olson EN. 2010. MicroRNA regulatory networks in cardiovascular development. Dev Cell 18: 510-525.

Mendell JT. 2008. miRiad roles for the miR-17-92 cluster in development and disease. Cell 133: 217-222. 
S. Landskroner-Eiger et al.

Mu P, Han YC, Betel D, Yao E, Squatrito M, Ogrodowski P, de Stanchina E, D'Andrea A, Sander C, Ventura A. 2009. Genetic dissection of the miR-17 $\sim 92$ cluster of microRNAs in Myc-induced B-cell lymphomas. Genes Dev 23: 2806-2811.

Murchison EP, Partridge JF, Tam OH, Cheloufi S, Hannon GJ. 2005. Characterization of Dicer-deficient murine embryonic stem cells. Proc Natl Acad Sci 102: 12135-12140.

Murchison EP, Stein P, Xuan Z, Pan H, Zhang MQ, Schultz RM, Hannon GJ. 2007. Critical roles for Dicer in the female germline. Genes Dev 21: 682-693.

Nicoli S, Standley C, Walker P, Hurlstone A, Fogarty KE, Lawson ND. 2010. MicroRNA-mediated integration of haemodynamics and Vegf signalling during angiogenesis. Nature 464: 1196-1200.

O’Donnell KA, Wentzel EA, Zeller KI, Dang CV, Mendell JT. 2005. c-Myc-regulated microRNAs modulate E2F1 expression. Nature 435: 839-843.

Oettgen P. 2006. Regulation of vascular inflammation and remodeling by ETS factors. Circ Res 99: 1159-1166.

O’Rourke JR, Georges SA, Seay HR, Tapscott SJ, McManus MT, Goldhamer DJ, Swanson MS, Harfe BD. 2007. Essential role for Dicer during skeletal muscle development. Dev Biol 311: 359-368.

Ota A, Tagawa H, Karnan S, Tsuzuki S, Karpas A, Kira S Yoshida Y, Seto M. 2004. Identification and characterization of a novel gene, C13orf 25, as a target for 13q31-q32 amplification in malignant lymphoma. Cancer Res 64: 3087-3095.

Otsuka M, Jing Q, Georgel P, New L, Chen J, Mols J, Kang YJ, Jiang Z, Du X, Cook R, et al. 2007. Hypersusceptibility to vesicular stomatitis virus infection in Dicer1-deficient mice is due to impaired miR24 and miR93 expression. Immunity 27: 123-134.

Otsuka M, Zheng M, Hayashi M, Lee JD, Yoshino O, Lin S Han J. 2008. Impaired microRNA processing causes corpus luteum insufficiency and infertility in mice. J Clin Invest 118: 1944-1954.

Poliseno L, Tuccoli A, Mariani L, Evangelista M, Citti L, Woods K, Mercatanti A, Hammond S, Rainaldi G. 2006. MicroRNAs modulate the angiogenic properties of HUVECs. Blood 108: 3068-3071.

Poy MN, Eliasson L, Krutzfeldt J, Kuwajima S, Ma X, Macdonald PE, Pfeffer S, Tuschl T, Rajewsky N, Rorsman P, et al. 2004. A pancreatic islet-specific microRNA regulates insulin secretion. Nature 432: 226-230.

Pulkkinen K, Malm T, Turunen M, Koistinaho J, YlaHerttuala S. 2008. Hypoxia induces microRNA miR-210 in vitro and in vivo ephrin-A3 and neuronal pentraxin 1 are potentially regulated by miR-210. FEBS Lett 582: 2397-2401.

Rayner KJ, Suarez Y, Davalos A, Parathath S, Fitzgerald ML, Tamehiro N, Fisher EA, Moore KJ, Fernandez-Hernando C. 2010 . MiR-33 contributes to the regulation of cholesterol homeostasis. Science 328: 1570-1573.

Ruby JG, Jan CH, Bartel DP. 2007. Intronic microRNA precursors that bypass Drosha processing. Nature 448: $83-86$.

Small EM, Sutherland L, Rajagopalan K, Wang S, Olson EN 2010. MicroRNA-218 regulates vascular patterning by modulation of slit-robo signaling. Circ Res 107: 1336-1344.

Stefani G, Slack FJ. 2008. Small non-coding RNAs in animal development. Nat Rev Mol Cell Biol 9: 219-230.

Suarez Y, Sessa WC. 2009. MicroRNAs as novel regulators of angiogenesis. Circ Res 104: 442-454.

Suarez Y, Fernandez-Hernando C, Pober JS, Sessa WC. 2007. Dicer dependent microRNAs regulate gene expression and functions in human endothelial cells. Circ Res 100: $1164-1173$.

Suarez Y, Fernandez-Hernando C, Yu J, Gerber SA, Harrison $\mathrm{KD}$, Pober JS, Iruela-Arispe ML, Merkenschlager M, Sessa WC. 2008. Dicer-dependent endothelial microRNAs are necessary for postnatal angiogenesis. Proc Natl Acad Sci 105: 14082-14087.

Tang F, Kaneda M, O'Carroll D, Hajkova P, Barton SC, Sun YA, Lee C, Tarakhovsky A, Lao K, Surani MA. 2007. Maternal microRNAs are essential for mouse zygotic development. Genes Dev 21: 644-648.

Trang P, Weidhaas JB, Slack FJ. 2008. MicroRNAs as potential cancer therapeutics. Oncogene 27: S52-S57.

van Rooij E, Olson EN. 2007. MicroRNAs: Powerful new regulators of heart disease and provocative therapeutic targets. J Clin Invest 117: 2369-2376.

Ventura A, Young AG, Winslow MM, Lintault L, Meissner A, Erkeland SJ, Newman J, Bronson RT, Crowley D, Stone JR, et al. 2008. Targeted deletion reveals essential and overlapping functions of the miR-17 through 92 family of miRNA clusters. Cell 132: 875-886.

Vester B, Wengel J. 2004. LNA (locked nucleic acid): Highaffinity targeting of complementary RNA and DNA. Biochemistry 43: 13233-13241.

Volinia S, Calin GA, Liu CG, Ambs S, Cimmino A, Petrocca F, Visone R, Iorio M, Roldo C, Ferracin M, et al. 2006. A microRNA expression signature of human solid tumors defines cancer gene targets. Proc Natl Acad Sci 103: 2257-2261.

Wang S, Aurora AB, Johnson BA, Qi X, McAnally J, Hill JA, Richardson JA, Bassel-Duby R, Olson EN. 2008. The endothelial-specific microRNA miR-126 governs vascular integrity and angiogenesis. Dev Cell 15: 261-271.

Wang XH, Qian RZ, Zhang W, Chen SF, Jin HM, Hu RM. 2009. MicroRNA-320 expression in myocardial microvascular endothelial cells and its relationship with insulin-like growth factor-1 in type 2 diabetic rats. Clin Exp Pharmacol Physiol 36: 181-188.

Wienholds E, Kloosterman WP, Miska E, Alvarez-Saavedra E, Berezikov E, de Bruijn E, Horvitz HR, Kauppinen S, Plasterk RH. 2005. MicroRNA expression in zebrafish embryonic development. Science 309: 310-311.

Wu F, Yang Z, Li G. 2009. Role of specific microRNAs for endothelial function and angiogenesis. Biochem Biophys Res Commun 386: 549-553.

Wurdinger T, Tannous BA, Saydam O, Skog J, Grau S, Soutschek J, Weissleder R, Breakefield XO, Krichevsky AM. 2008. miR-296 regulates growth factor receptor overexpression in angiogenic endothelial cells. Cancer Cell 14: 382-393.

Xiao J, Yang B, Lin H, Lu Y, Luo X, Wang Z. 2007. Novel approaches for gene-specific interference via manipulating actions of microRNAs: Examination on the 
miRNAs as Modulators of Angiogenesis

pacemaker channel genes HCN2 and HCN4. J Cell Physiol 212: 285-292.

Xiao C, Srinivasan L, Calado DP, Patterson HC, Zhang B, Wang J, Henderson JM, Kutok JL, Rajewsky K. 2008. Lymphoproliferative disease and autoimmunity in mice with increased miR-17-92 expression in lymphocytes. Nat Immunol 9: 405-414.
Xu P, Vernooy SY, Guo M, Hay BA. 2003. The Drosophila microRNA Mir-14 suppresses cell death and is required for normal fat metabolism. Curr Biol 13: 790-795.

Yang WJ, Yang DD, Na S, Sandusky GE, Zhang Q, Zhao G. 2005. Dicer is required for embryonic angiogenesis during mouse development. J Biol Chem 280: 93309335. 


\section{$\&_{\mathrm{CSH}}^{\infty} \&$ Cold Spring Harbor

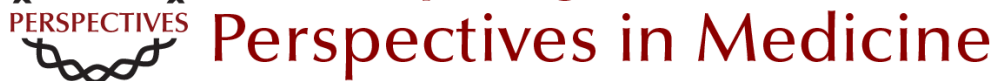

\section{miRNAs as Modulators of Angiogenesis}

Shira Landskroner-Eiger, Isabelle Moneke and William C. Sessa

Cold Spring Harb Perspect Med 2013; doi: 10.1101/cshperspect.a006643 originally published online November 20, 2012

\section{Subject Collection Angiogenesis}

Extracellular Matrix Regulation of Vascular Morphogenesis, Maturation, and Stabilization George E. Davis and Scott S. Kemp

Endothelial Cell-Pericyte Interactions in the Pathogenesis of Cerebral Cavernous Malformations (CCMs) Wang Min and Jenny Huanjiao Zhou

Lymphatic Clearance and Pump Function Jerome W. Breslin

Platelets and (Lymph)angiogenesis Harvey G. Roweth and Elisabeth M. Battinelli

Modeling Brain Vasculature Immune Interactions In Vitro Ruth Lyck, Hideaki Nishihara, Sidar Aydin, et al.

Human Endothelial Colony-Forming Cells Juan M. Melero-Martin

\section{The Beauty and Complexity of Blood Vessel} Patterning

Victoria L. Bautch and Yoh-suke Mukouyama

Endothelialitis, Microischemia, and

Intussusceptive Angiogenesis in COVID-19 Steven J. Mentzer, Maximilian Ackermann and Danny Jonigk
Regulation of the Blood-Brain Barrier in Health and Disease Cara C. Rada, Kanako Yuki, Jie Ding, et al.

Targeting Angiogenesis via Resolution of Inflammation

Abigail G. Kelly and Dipak Panigrahy

Notch Signaling in the Vasculature: Angiogenesis and Angiocrine Functions

Sana S. Hasan and Andreas Fischer

Signal Transduction and Gene Regulation in the Endothelium

Michel V. Levesque and Timothy Hla

Buttons and Zippers: Endothelial Junctions in

Lymphatic Vessels

Peter Baluk and Donald M. McDonald

Endothelial Cell Fate Determination: A Top Notch Job in Vascular Decision-Making

L.A. Naiche, Stephanie R. Villa and Jan K. Kitajewski

Leukocyte Trafficking in Lymphatic Vessels Aline Bauer, Hazal Tatliadim and Cornelia Halin

Lymphatic Tissue and Organ Engineering for In Vitro Modeling and In Vivo Regeneration Anna M. Kolarzyk, Gigi Wong and Esak Lee

For additional articles in this collection, see http://perspectivesinmedicine.cshlp.org/cgi/collection/ 